Journal of Social Sciences 7 (2): 104-112, 2011

ISSN 1549-3652

(C) 2010 Science Publications

\title{
Teaching Indigenous American Culture and History: Perpetuating Knowledge or Furthering Intellectual Colonization?
}

\author{
Michael Kent Ward \\ Department of History, College of Social and Behavioral Sciences, \\ California State University, Northridge, 18111 Nordhoff Street, Northridge, CA 91330-8250 USA
}

\begin{abstract}
Problem statement: This study addresses a number of ongoing and important issues related to teaching the history and culture of Native Americans in the public setting. As part of the social science curriculum, the study and academic interpretations of American Indian culture and history regularly attracts educators and students alike, but remains problematic for reasons of cultural property and identity. Of particular concern are matters related to the accuracy and purposes of such instructional content and problems of cultural representation, cultural boundaries and cultural and/ or intellectual property. A related question concerns problems associated with limiting access to cultural knowledge versus increased demands for open access to information. Approach: By examining the historiography related to this subject and exploring other mainstream and indigenous academic and traditional indigenous perspectives on this topic, the scope of the problem of American Indian cultural misrepresentation can be ascertained, while the complexities of these issues may also be recognized. A key aspect of this study is its emphasis on indigenous perspectives, which often stand in contrast with those of mainstream academic thought on this and related topics. Though legal questions arise from such an examination, the issues addressed here are largely ethical in nature. Results: From traditional indigenous and indigenous academic perspectives, the unauthorized use of ceremonies, sacred songs and stories, or ritual and other material culture objects constitutes a theft of cultural and/ or intellectual property. The fact that this problem persists despite many decades of indigenous criticism indicates the continuation of an overall non-indigenous disregard for American Indian authority. Thus, the perpetuation of cultural misrepresentation and the continued theft of cultural and/ or indigenous intellectual property serves to further the historic process of non-indigenous colonization of Native American cultures. Conclusions/Recommendations: In most cases, solutions to the problems of cultural property and misrepresentation are obvious but difficult to carry out due to the general use of and emphasis on authorities not recognized by traditional indigenous peoples. This study addresses that fact and concludes that everyone involved (teachers, students and indigenous peoples) are best served when traditional American Indian authorities are regularly consulted, with regard to matters involving public presentations and interpretations of indigenous cultures. The single greatest remedy to the problems described involves open communication and the unbiased recognition of indigenous authority. Due to the complexities of these and related issues, further contributions by indigenous peoples, expanded study and analysis by academics are recommended.
\end{abstract}

Keywords:American Indian culture and history, intellectual colonization, intellectual and cultural property, indigenous identity, Ventura County, academic interpretations, specific stereotypes, perpetuating knowledge

\section{INTRODUCTION}

From most popular perspectives, learning about indigenous American peoples and their cultures can be both informative and fun. Students of all ages are almost always eager to learn about Native Americans. Thus, they are easily drawn into an intellectual environment where they can imagine what aboriginal life was like before foreign colonizers penetrated the
Indian nations to undermine indigenous claims to their homelands, desecrating and possessing them while exterminating bands and tribes and forcing surviving native peoples to relocate elsewhere. Setting aside the obvious historical conflicts involving some of the most hideous aspects of American history, many of today's elementary and secondary school students are regularly exposed to interactive and hands-on instruction about the cultures and life ways of indigenous peoples. 


\section{J. Social Sci., 7 (2): 104-112, 2011}

Reflecting a hunger to know and a desire to experience something of another culture in an increasingly global environment, interpretations of indigenous American cultures through educational presentations are widely held and remain very popular. Such instruction is most often carried out as a part of the curricula of elementary and secondary education and within the contexts of community parks and recreation activities and museum programs. The goals of this kind of education are usually carried out with good intentions, but in practice such presentations about Native American cultures are also just as often romanticized, presenting problems that usually go unnoticed or ignored for a number of reasons. Such "exotification" (Churchill, 1998) of indigenous peoples and accompanying distortions of their cultures were subjects addressed decades ago by an aboriginal Australian critic with the following statement: "Our heritage-our playground" (ColwellChanthaphonh, 2009). The resulting cultural misrepresentation and related issues of stereotyping remain significant enough to question the validity of programs dealing with indigenous peoples. Such problems are pervasive and often painful for the Native people under examination and discussion. The hurts that they experience are most often not recognized or easily acknowledged by responsible parties as indigenous American educator Dierdre Almeida has noted, adding that, most corrective efforts fail and that, in the end the effort to rectify cultural misinformation "succeeds only in replacing one [older] unrealistic portrayal with another" (Almeida, 1996).

This essay addresses a number of complex issues related to cultural property and both the popular and academic portrayals of indigenous peoples. Suggestions of ways to resolve these and related problems are also offered, with the hope that they will satisfy the needs of educators and Native peoples at the same time. The goal herein is not to bring an end to courses about or involving indigenous cultures and related presentations; that is not realistic and brings with it other nonproductive ends. It is not practical to eliminate such instruction, but it is necessary to enhance its legitimacy.

American Indian studies as a discipline in the social sciences: Since the late 19th century aboriginal Americans, their cultures and histories have been discussed through various academic disciplines and portrayed through popular media. Such depictions and associated interpretations are regularly offered for public scrutiny through presentations and at venues related to the social sciences and natural history. The interest in Native American culture and history is easy to understand; the story of the United States, like the rest of the Americas, is infused with narratives and images of indigenous peoples, reflecting a wide range of conflicts and impressions that have piqued the imaginations of Europeans and others since the late 15 th century. As a result of several centuries of conflicts and more than a century of other-thanindigenous interest in aboriginal culture, American Indian themes have appeared in many non-Indian cultural expressions (Jenkins, 2004). Thus, aspects of American Indian history and culture have become and remain important parts of education from elementary school through university levels of instruction. Native American ecology, knowledge and uses of indigenous flora, fauna, minerals and other natural resources continue to receive much scholarly attention amidst growing indigenous resistance (Brown, 2004; Pewewardy, 1998; Welch, 2002; Yellowtail et al., 1980). Moreover, knowledge about Indian uses of such resources and their historic relationship with the environment are regularly deemed essential to the collective understanding of our place in the world today. Often, such studies bear the lofty hope that by gaining an awareness of Native American cultural practices, answers may be found to modern problems shared by all. Nevertheless, in an environment of expanding access to information, the unlimited right to investigate and use knowledge specific to indigenous peoples and cultures is increasingly deemed inappropriate by indigenous peoples themselves (Brown, 1998b; 2004; Welch, 2002).

Relevant background, experiences of the author, statement of the problem and methods of study and evaluation used: From decades of lecturing and teaching to a diverse array of students or before varied audiences in Southern California, it became apparent to the author that a wide range of cultural biases with regard to Native peoples are deeply ingrained in the American mind and remain perpetuated through many institutional programs of instruction. Such prejudicial expressions usually appear innocent and sympathetic to indigenous Americans, but often they are subtly disrespectful. Rarely, they are deliberately antagonistic. For more than a decade the author's audiences have primarily been college and university students, including those who are working in or who are about to enter teacher credential programs. Between the early 1980s and 2000 the author taught or participated in programs and classes for adults and workshops for students of primary through secondary schools. Working as a "free-lance" naturalist and instructor for 


\section{J. Social Sci., 7 (2): 104-112, 2011}

various public agencies these programs involved daylong, weekend and multi-week courses of instruction at sites that included natural history museums, national, state and regional parks and outdoor schools. Most of these courses involved a variety of natural history themes, ranging from wilderness survival, marine ecology, natural resources and their uses and Native Americans. In 1987 and 1988 the author participated with a number of teachers, anthropologists and Native Americans in the "Chumash Culture Youth Project," sponsored by the Santa Barbara Museum of Natural History at Santa Barbara, California. As a participant in the program held at the Ventura County Museum of History and Art at Ventura, California and as co-site coordinator with the late Chumash tribal elder Vincent J. Tumamait for the subsequent program held at The Ojai Art Center in Ojai, California, the author realized the effectiveness of hands on, experiential instruction that has since become widely employed in similar projects in California and throughout the United States. During this same period of time, observations and suggestions were made to the author by a number of indigenous friends and acquaintances from various Mid-West American Indian communities and reservations, who questioned the validity of such instruction, often noting that their own people would have little tolerance for the kind of cultural tourism that was being engaged in throughout Southern California. Since that time the author has mulled over these points and questions, while the programs continued unabated, offering both a steady (and needed) source of employment for many Native Americans and nonIndian access to peoples and cultures usually deemed exotic, even mysterious. Over the past two decades such programs have increased to become pervasive features of education nation-wide. As these programs have spread, so too has its criticism from many traditional American Indians and activists. Indeed, as these programs proliferate, questions regarding their legitimacy remain.

By looking into such programs and their evolution over time, examples of persistent misrepresentation of indigenous cultures and peoples can be observed, verified and otherwise examined. Through an investigation into the works of academics, including historians, anthropologists, religious studies scholars and American Indians, further understandings of relevant issues can be ascertained and likely solutions to this and related problems may be found. What follows in this study is such an examination with suggestions for possible solutions.

Problems of cultural tourism and indigenous American representation: Social Science curricula that center on indigenous cultures are most often rooted in the interests and perspectives of hegemonic nonIndian society, reflecting its interpretive rules and definitions (Ward, 2001). Critics of American Indian interpretive presentations take issue with a range of common characteristics that these programs and interpretations share, including cultural misrepresentation, the usurpation of indigenous authority and the violation of cultural property. A particular issue noted by these detractors is the conventionalized focus on ancient or pre-Columbian cultures, something that detracts from current Indian realities. Often perpetuating romanticized notions masked by claims of academic legitimacy, what used to be takes on greater meaning than present societal conditions and the needs of Native Americans (Paul Chaat, 2009). The problem is that non-indigenous definitions of the past are seen to possess greater integrity regarding their "Indian-ness" than modern Indian reality does today. Thus, living Native Americans are often seen as removed from their former cultural selves, while their complaints about misrepresentation are regularly discounted.

Another problem has to do with cultural property and the use of cultural items-both tangible and intangible-by non-Indians and Native Americans alike, who lack the support of traditional Indians and indigenous authorities for such uses (Brown, 1998a). An associated feature of this issue has to do with the idea that such items taken outside their cultural contexts lose their efficacy and meaning and therefore should not be used. In the end, the main problem again, is one of identity as Native Americans realize the undermining of their authority and the theft of their culture by persons who freely claim the right to re-imagine indigenous peoples according to new definitions. In other words, old stereotypes and biases become replaced with new ones. Just as nationalist historian Benedict Anderson described nations as "imagined communities," so too are the cultural features within nations (Anderson, 1991). In the centuries-old effort to justify the theft of indigenous owned lands, resources and the subjugation and subordination of conquered and colonized peoples, colonizing nations have long imagined themselves as triumphant and superior, reimagining the definitions of indigenous peoples at the same time. Meanwhile, subordinate peoples are required to conform to new definitions and roles 
according to an overall global (and capitalist) scheme, as historian J.M. Blaut has illustrated (Blaut, 1993). In a similar vein, historian Eric Wolf has described the "economic and political side to the formation of idea systems," and the fact that upon their formation, they can "become weapons in the clash of social interests (Wolf, 1997)." For indigenous Americans such collisions of cultural interests and interpretations often arise from new definitions of Native culture that are synonymous with non-Indian projections.

Thus, from the critics' point of view, cultural tourist presentations, even those tied to formal education, tend to redefine indigenous peoples and their cultures and histories in ways that meet the needs and expectations of the tourists and detract from truly indigenous definitions and identities. Moreover, such redefinitions often result in the emergence of new and imagined biases and stereotypes. Whether seen as mild or overtly antagonistic, such new non-Indian biases toward American Indians in any of these settings thus reflect a synthesis of cultural attitudes and notions about the other. The irony is that many of these new biases have been influenced by information intended to end the historical legacy of racial prejudice. These new expressions, though they appear benign or sympathetic, in actuality serve to diminish indigenous agency and identity (Almeida, 1996; Colwell-Chanthaphonh, 2009; Smith, 2009b).

Experiential modes of instruction, cultural tourism and associated conflicts: Hands-on activities can be particularly useful in successful teaching and learning, meeting the needs of what Professor of Education Íbrahim Yaşar Kazu has described as different and varied "learning styles" for the effective conveyance of knowledge (Kazu, 2009). Thus, various activities that involve crafts, story telling, games, singing and dancing are regularly employed in cultural programs about American Indians. Such activities are seen as fun and expose students to different learning experiences that encourage attentiveness and creativity (ibid.). Following similar pedagogical models, a common technique used in classes and presentations on American Indians involves the brief immersion of students into an experiential and hypothetical reconstruction of Native American culture. One highly successful southern California project for elementary school-aged students that utilizes such an approach is the "Chumash Youth Program" held regularly for over two decades at the Museum of Ventura County (formerly the Ventura County Museum of History and Art), in Southern California. The Chumash Youth
Program was closely based on models established at the Santa Barbara Museum of Natural History in the 1980s. Both programs employed the use of an "opening circle" made of white sage (Salvia apiana Jepson) around which the students sat and began with a simple greeting: haku, or "hello" in one of the Chumashan languages, followed by a well known welcome song. Such programs as those at both venues involved teachers and presenters who were American Indians (including Chumash) and non-Indians. Recent versions of these classes were still actively subscribed to in 2010 and have long received the praise and enthusiasm of the general public (Museum of Ventura County, 2010). It should be noted that the above named institutions, especially the Santa Barbara Museum of Natural History, have taken great pains to establish and maintain successful and positive working relationships with indigenous peoples. Their programs thus enjoy considerable support from Indians and non-Indians alike. Sometimes however, such public presentations of indigenous cultures are made-often innocently-by people who do not possess Native American endorsement, or by persons of indigenous identity or descent who lack the support of tribal or cultural authorities.

Such re-enactments of culture typically involve self styled indigenous activities defined by authorities and educators who, despite their credentials, are most often non-Indians or are without ancestral, familial, or similar ties to the traditional cultures under discussion. Working under the best of stated intentions such presentations are aimed at cultural specificity and accuracy in order to dispel old stereotypes, as described in many curriculum plans (Hopkins, 2006). Just as often however, they tend to perpetuate notions about the exoticness of such cultures. An early example of one of these experiential programs in Southern California was recounted several years ago in an article by journalist Lori Steinhauer and published in the leading Ventura County, California newspaper at that time:

A primitive spirit filled the museum's brick courtyard where 18 students gathered after school . . . The wind kicked up wafts of scent from the sacred Indian sage circle around which the children were seated on mats ... the youths chiseled sandstone beads with finger drills of chert . . they smoothed their beads with sharkskin and horsetail fern. The children wore tags with the Indian names they chose. Alulkai, which means dolphin, was selected by at least a half 
dozen girls. Bird names, such as Kak for raven, Wit for condor and Mahiwo for bald eagle were popular among the boys.

Of course, this media description was meant for a regional non-Native audience; it's obvious biases were never challenged nor were they recognized by the readers, as evidenced by the lack of any negative or challenging public comments in the editions that followed. On the surface such expressions of nonIndian ethnocentrism and romantic sentimentality might seem fairly innocent. Underlying them however, is an old colonial exploitative imperialism that objectifies the other and preys upon indigenous peoples and cultures.

The teaching models and methods described above carry with them long-standing benefits. Nevertheless, they also perpetuate a number of issues that tend to go unnoticed in the face of the Public's enjoyment. Yet it is precisely due to these problems that the most virtuous of efforts to promote an "antibias perspective" regarding indigenous peoples, are betrayed (Almeida, 1996). Moreover, non-Indian attitudes such as those reflected in the newspaper passage above remain acceptable-even justified-by a general and commonly held ignorance of American Indian social and economic realities (Welch, 2002).

Portrayals and presentations of American Indian cultures such as those described above are widespread and have been widely practiced for decades across the United States. American Indian educator Deirdre Almeida of the University of Massachusetts calls this kind of instruction the "tourist approach," noting its inherent inadequacies and tendency to perpetuate a range of biases by "trivializing" American Indians and their cultures:

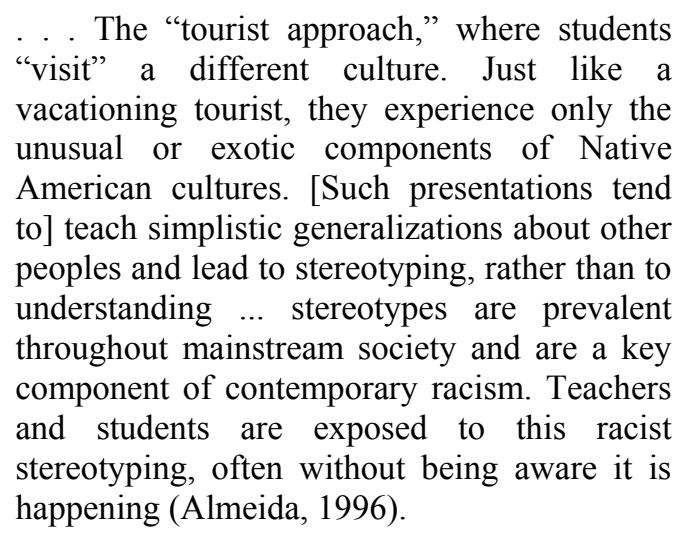

Of course, another kind of "American Indian Tourism" connected to what is popularly referred to as "Indian Gaming" has benefited many tribes for years, providing the monetary power that allows Native Americans to effectively influence perspectives regarding their own stories (Casino Enterprise Management, 2008). Nevertheless, the vast majority of Indian peoples still do not dominate or possess authority over the narratives of their own history. Despite the best efforts to treat specific cultures with accuracy and dispel the historic tendency to depict American Indians according to old forms of bias, new culturally specific stereotypes often emerge. Regardless of its general application to a race or specific to a particular people, mischaracterization is indeed a recurring problem. Though not always obvious, many seemingly benevolent portrayals of American Indians tend to oversimplify their cultures, inevitably describing them with generalities that contribute to stereotyping.

In a program similar to those described for Southern California, an acclaimed program at "Escuela Tlatelolco" in Denver, Colorado brings together a diverse student population of mixed races and ethnicities, including American Indians. Beginning each day's lessons by "smudging" with smoldering copal, students assemble for group sharing in a "talking circle." At Escuela Tlatelolco, students "can also participate in the Lakota drum group," according to its organizers (Ebisch, 2005). Of course, indigenismo is an important component of 21 st-century Latin American (and especially Mexican) identity, justifying the use of commonly shared Native American cultural elements and motifs. It is not clear, however, if Lakota people support what is apparently the non-Lakota use of Lakota songs. Certainly the purposes for using another culture's songs are well intended in this case. Some (if not many) Lakota people however, might be concerned about the proper context for the use of their songs, especially if they carried spiritual meanings and uses. Even if someone who is Lakota is supervising the use of Lakota songs, if they are deemed sacred, as indicated by the ceremonial context of the student gathering, it would be expected that Lakota spiritual leaders have been be consulted. Despite the popularity and importance of gaining knowledge about aboriginal American cultures and history, questions of cultural legitimacy and honesty and appropriate cultural contexts for such practices and presentations persist.

Misrepresenting indigenous cultures and threats to American Indian identity: A long-standing issue regarding the interpretation of indigenous cultures is the potential for the misrepresentation of cultural traditions, as described above. Universally understood, education is central to the conveyance of national and cultural worldviews as well as shaping and changing cultural 
identities, as educator Nihat Aycan has shown with regard to post-World War I Turkey (Aycan, 2005). Unlike the Turkish example, where indigenous unity gave rise to a new national identity and the creation of modern Turkey, however, education in the U.S. tends to perpetuate perspectives of indigenous Americans that can destabilize American Indian unity and weaken Native American identity. Such tendencies come through a general cultural misrepresentation through education and in other ways. This issue remains a significant problem that many traditional Native Americans have long pointed out and has been recently described by anthropologists, historians and religious scholars (Brown, 2004; Brown and Williams, 2004; Jenkins, 2004; Pewewardy, 1998; Welch, 2002). From such perspectives, a series of questions arise: are such cultural reconstructions accurate? Do they truly inform students about the realities of the past, or, for that matter, do they inform about the present? Perhaps more importantly from indigenous perspectives, do simplified and potentially inaccurate depictions of American Indian life end with the reification of false perspectives? If the last question is answered affirmatively as many indigenous authorities have argued, then some of the reasons for the perpetuation of many biases and popular misconceptions about Native Americans may be better understood and possibly corrected.

As seen in the examples already described, it is often the case that expressions of indigenous spirituality accompany many standard interpretations of American Indians. For example, simplified versions of Native American purification ceremonies, sacred histories or myths, songs, dances and other cultural elements are frequently included in presentations about indigenous cultures, without correct or adequate interpretation related to the deep meaning attached to them, or sans appropriate contexts for their use. Comanche-Kiowa educator Cornel Pewewardy has warned against using indigenous spiritual elements in such presentations:

Children should not dance Hollywood Indianstyle, nor should children beat on a drum and try to sing traditional songs. Social and traditional songs and dances have religious meaning for many tribes and any attempt at imitation is ridicule. The ability to beat on the drum and sing song is earned through tribal rites of passages (Pewewardy, 1998).

This kind of misappropriation of Native American spiritual practices is a particular problem within the popular "New Age" spiritual movement, where "plastic medicine men [and women]" perpetuate a conflated mix of conventionalized non-Indian, pseudo-American Indian and misinterpreted Native American philosophy and ceremonies, often while pretending to possess secret knowledge from obscure indigenous sources (Hagan, 1992; Jenkins, 2004). For many traditional Indian people, these developments are seen as a threat to their intellectual sovereignty and thus seek to halt such misrepresentations, as recently described by Lakota leader Arvol Looking Horse (Looking Horse, 2003). While the relatively lesser examples of misrepresentation in public education might appear benign by comparison with such gross misappropriation of indigenous spirituality, both practices are related. This problem is pervasive in Western cultures and is evident throughout the United States and the Americas, Europe, Asia and Australia, posing a threat to the cultural sovereignty of indigenous peoples worldwide (Welch, 2002).

From the traditional point of view held by many American Indians, such things as their ceremonies and related paraphernalia, symbols, songs and sacred narratives belong exclusively to the people and the cultures from whence they came. In other words, as seen from indigenous perspectives, they are cultural and intellectual properties, deserving of the same protections as the intellectual property produced by artists, musicians and writers. Though most Americans understand copyright, even when they violate it, extending such rights to the property collectively held by Native Americans is apparently a difficult concept to grasp or agree with for many, if not most people. At the heart of this problem are copyright issues, but also those pertaining to indigenous identity, as non-Indians increasingly claim free access to and ownership of Native ceremonies and associated elements as noted (Brown, 1998a). Another related issue concerns Native American mavericks who grant permission to access such cultural materials without the support of their tribes or communities, as described by historian of religions Philip Jenkins:

The issue of tribal identity is sensitive. Indian activists complain that most of those marketing Native spirituality have little or no claim to Indian-ness and are thus engaged in cultural theft. (A different kind of rage is directed against entrepreneurs who are unquestionably Indian, who are denounced as quislings and sell-outs.) Certainly, ethnic identity can be difficult to prove. If a person claims to be Cheyenne or Navajo, that can usually be settled definitively by reference to tribal records, but many of the key writers and gurus [of Native American spirituality] speak 


\section{J. Social Sci., 7 (2): 104-112, 2011}

more generally of a heritage which is often traced to multiple peoples. The virtue of that claim is that it is basically immune to disproof (Jenkins, 2004).

Jenkins has also noted the popularity among charlatans, of claiming "Toltec" cultural connections and identity, adding that, "they [Toltecs] never developed the sophisticated writing systems associated with Mayas or Aztecs," and thus, "statements about them can be neither checked nor disproved," thus making such claimed identities is not only difficult to verify, but specious as well (Jenkins, 2004). Regardless of the obfuscating methods used, such misrepresentations undermine legitimate indigenous claims to their own cultures, offering instead, simplistic and conventionalized interpretations that appeal to nonAmerican Indians.

This is an old issue, rooted in Western notions of racial and ethnic otherness that, in the 20th century became expressed by non-indigenous peoples and their interests in and growing identification with, stereotypical portrayals of colonized peoples. When the problem is perpetuated by American Indians themselves in violation of their people's wishes, it exists as a modern version of the "betrayal" theme commonly found in Native American history (Josephy, 1965). Moreover, it reveals the degree to which Native Americans "are not a homogenous group with a unified response to appropriate practices," as historian of religions Christina Welch has described (Welch, 2002). When such practices appear as the adopted expressions of non-Indians and involves the presumed ownership of indigenous culture, they become another form of continued colonization and the persistent acquisition of Native American property. Professor Pewewardy's eloquent and forceful condemnation goes even further, describing it as a continuation of the historical process of American Indian extermination:

Today I see silent genocide in the way indigenous people are integrated and reinvented by non-Indians. Appropriation of indigenous ceremonies, religions and identities has been the most threatening practice. Examples could be using Indians as mascots and logos in sports culture; new age shamanism; and eugenics research. This blatant disrespect for the rights and religious practices of indigenous peoples may prove to be one of the most destructive forces of oppression yet, as American racism steals precious mental and physical treasures of the soul. Genocide is contagious. Unless interrupted by healing grace, the atrocities of the past become ghosts within the cultural memory of a people crying out for justice (Pewewardy, 1998).

Intellectual colonization not only threatens to erode the influences of traditional cultural authority, but it can destroy American Indian identity, as non-Indians eventually claim possession of things indigenous by their ability to define them in non-indigenous terms. Many popular writers have been able to successfully obscure this problem behind a cloak of presumed legitimacy. For example, in her descriptions of the untruthful or mistaken non-indigenous portrayals of Aboriginal Australians and North American Indians, Welch has noted the perpetuation of a common "white" myth about the "right white person to whom to entrust [indigenous] cultural values." Rooted in the popular and invented tales of noted charlatans like Carlos Castañeda, this common notion feeds the historic pattern of non-indigenous claims to ownership of things Native American and the presumption that modern Indians betray an ancestral past as defined by nonindigenous authorities. In the final product what results are the denial of Native American agency, the "continuation of colonialism," and the loss of indigenous identity (Welch, 2002). The question then, is: how can American Indian themes be adequately explained and utilized in academic settings and instruction in the social sciences without violating ethical responsibilities for respecting indigenous cultural property claims or rights? The answer is plain but putting it to use is not likely to be an easy task for many people.

Additional considerations from indigenous sources: American Indian leaders from across the United States convened a meeting in 1980 at the Northern Cheyenne Nation in Montana. Their primary purpose was to address the problem of imposters who pose as "medicine people" for profit. In the resolution that this council drafted, a series of simple questions were offered by which all people could seek qualifications and thereby expose charlatans. Among the proposed questions included the following: "What Nation does the person represent?" and "who instructed them and where did they learn?" (Yellowtail et al., 1980). These and similar or related questions connected to the charging of fees for ceremonies can be useful in determining-from Native American community (not individual) perspectives-who is qualified to speak and teach on behalf of American Indian peoples or perform spiritual 


\section{J. Social Sci., 7 (2): 104-112, 2011}

services in the name of such peoples. As a model, it can be applied to anyone who claims to represent any indigenous culture or people in publications and public venues.

With public instruction and education in mind, additional considerations include whether or not such presentations are accurate, according to legitimate indigenous definitions. If so, it might be appropriate to ask how the prehistoric and historic past contrasts with Indian life today. Such realities of the present include problems associated with late-stage colonization: poverty, alcoholism and other addictions, various forms of abuse and the loss of indigenous languages and the cultures they support. It should be noted that programs that use many of the methods noted above for nonIndian and mixed audiences, exist as well in courses that serve American Indian youth exclusively. Sourced in traditional cultures these methods are readily recognized as traditional in form by Native American students. Rather than offering a focus of the "tourist" type described above, such presentations to indigenous audiences instead stress the virtues of traditional culture, values and history and the benefits of drug and alcohol prevention. In these programs, which regularly take place at many tribal schools and museums, American Indian children and teens participate in traditional indigenous methods of learning that build community and self esteem. While they employ similar methods as other programs across the U.S. for nonIndian students in social science courses, the Native American versions are applied for different-and arguably more worthy-purposes (AAMHC, 2008; Smith, 2009a). In contrast to programs offered specifically for Indian students, non-Indian presentations about Native peoples are usually delivered in ways that focus on archaic and pre-historic forms of indigenous cultures and assumptions about their spirituality and ceremonies, or the historic recognition of their ecological values and cultural ties to the environment. What is glaringly missing in such non-indigenous depictions is information related to the issues facing the tribes today (Welch, 2002).

\section{CONCLUSION}

Communication is the solution: Given the widespread public attraction to indigenous American cultures and the chronic problem of cultural misrepresentation, questions pertaining to legitimacy must be asked. Added to those posed above can be included the following queries: in what ways do cultural programs created for consumption by a largely non-indigenous public encourage the misinterpretation of American
Indians? How do such presentations perpetuate a redefinition of Indian cultures that subverts traditional authority, replacing indigenous with non-indigenous definitions? Do such programs violate ethics related to intellectual and cultural property? How does one identify legitimate Native American tribal authorities and establish working relationships with them? These and related questions are important to consider for educators and teachers in the social sciences. The kind of indigenous authority recognition that these and related questions demand is not only appropriate, but it has successfully been applied to the use of eagle feathers for decades (Denver Colorado, 2009). Just as Federal law has served the protection of eagles, so can methods of authentication defined by indigenous peoples help protect endangered traditional American Indian cultures.

Solutions for the problems of misrepresentation and the misuse of cultural property are simple to identify but not always easy to carry out. First and foremost among these remedies would be to establish communication with tribal councils and governments. Long-standing demands made by Native leaders regarding their cultural sovereignty and property hold within them a willingness to make such connections. Employing teachers who have legitimate ties to and support from tribal governments is a key part of creating true representations of indigenous cultures and their histories. This is not a new suggestion and carries with it some potential pitfalls. Anthropologists Michael F. Brown and C. Williams for example, disagree that "close collaboration with host communities will eventually resolve most intellectual property concerns," adding that despite such efforts, old tensions and disputes remain, as new ones emerge (Brown and Williams, 2004). When it comes to anthropological field work, especially outside the United States, indeed, this may be the case. Considering American education, associated demands for access to information and the potential for collaborative relationships with urban Indians and many traditional peoples within the nation, however, communication and cooperation with recognized indigenous authorities, elders, tribal councils and reservation governments hold the best solutions to remedy the problems described. While not new or unique a proposal, it nonetheless remains the most do-able, providing perhaps the best hope to ending the legacy of prejudice and misrepresentation suffered by American Indians. Respecting indigenous cultural property and authority not only benefits Native peoples, but will go far to enhance the moral and intellectual integrity of the nation as well. 


\section{REFERENCES}

AAMHC, 2008. A:shiwi A:wan Museum and Heritage Center. Pathways to Zuni Wisdom. http://www.ashiwi-museum.org/pathways.html

Almeida, D.A., 1996. Countering Prejudice against American Indians and Alaska Natives through Antibias Curriculum and Instruction: ERIC Digest. ERIC Publications. http://www.eric.ed.gov/PDFS/ED400146.pdf

Anderson, B., 1991. Imagined Communities: Reflections on the Origins and Spread of Nationalism. 1st Edn., Verso, London, ISBN-10: 0860915468, pp: 224.

Aycan, N., 2005. The process of getting identity in turkish society: Kemalist education. J. Soc. Sci., 1: 136-140. DOI: $10.3844 /$ jssp.2005.136.140

Blaut, J.M., 1993. The Colonizer's Model of the World: Geographical Diffusionism and Eurocentric History. The Guilford Press.

Brown, M. F., 1998a. Can culture be copyrighted? Current Anthropol., 39: 193-222.

Brown, M. F., 1998b. Cultural records in question information and its moral dilemmas. Cultural Resou. Manage., 21: 18-20.

Brown, M.F. and C. Williams, 2004. Owning Culture: Anthropology and Its Intellectual Properties. Anthropology News Dialogue Commentary.

Brown, M.F., 2004. Who Owns Native Culture? 1st Edn., Harvard University Press, USA., ISBN-10: 0674016335, pp: 336.

Casino Enterprise Management, 2008. American Indian Tourism: Bringing Entertainment and Culture to Millions. Casino Enterprise Management. http://www.casinoenterprisemanagement.com/artic les/january-2008/american-indian-tourismbringing-entertainment-and-culture-millions, accessed 31 October 2010.

Colwell-Chanthaphonh, C., 2009. Reconciling American archaeology and Native America. MIT Press J., 138: 94-104. DOI: 10.1162/daed.2009.138.2.94

Denver Colorado, 2009. National Eagle Repository. U.S. Fish and Wildlife Service. http://www.fws.gov/mountain-prairie/law/eagle/

Ebisch, R., 2005. Escuela Tlatelolco's Three C's: Community, Culture and Caring. Spark Action For Children, For Youth and Chenge. http://www.connectforkids.org/node/3777

Hagan, H.E., 1992. The Plastic Medicine People Circle. Institute of Archetypal Ethnology Newsletter, September.

http://www.sonomacountyfreepress.com/features/s pirg-hagan.html
Hopkins, G., 2006. Are You Teaching The Real Story of the "First Thanksgiving"? Education World, Inc. http://www.educationworld.com/a_curr/curr040.shtml

Jenkins, P., 2004. Dream Catchers: How Mainstream America Discovered Native Spirituality.1st Edn., Oxford University Press, USA., ISBN-10: 0195161157, pp: 306.

Josephy, A.M., 1965. The Patriot Chiefs: A Chronicle of American Indian Leadership. 1st Edn., The Viking Press, USA., pp: 364.

Kazu, I.Y., 2009. The effect of learning styles on education and the teaching process. J. Soc. Sci., 5: 85-94. DOI: $10.3844 /$ jssp.2009.85.94

Looking Horse, A., 2003. Further Thoughts on the Protection of Ceremonies. New Age Fraud and Plastic Shamans. http://www.newagefraud.org/olh5.html

Museum of Ventura County, 2010. Nature's Palette: The Art of Meredith Brooks Abbott. Museum of Ventura County. http://www.venturamuseum.org/

Pewewardy, C., 1998. Fluff and feathers: Treatment of American Indians in the literature and the classroom. Equity Excellence Edu., 31: 69-76.

Smith, M.K., 2009a. Issues in Cultural Tourism Studies. 2nd Edn., Routledge, USA., ISBN-10: 041546711X, pp: 272.

Smith, P.C., 2009b. Everything You Know about Indians Is Wrong. 1st Edn., University of Minnesota Press, USA., pp:180.

Ward, C., 2001. Fantasies of the Master Race: Literature, Cinema and the Colonization of American Indians. 1st Edn., City Lights, USA., ISBN-10: 0872863484, pp: 261.

Welch, C., 2002. Appropriating the didjeridu and the sweat lodge: New age baddies and indigenous victims? J. Contemporary Religion, 17: 21-38. DOI: $10.1080 / 13537900120098147$

Wolf, E.R., 1997. Europe and the People without Histor: With a New Preface. 1st Edn., University of California Press, USA., ISBN-10: 0520048989, pp: 534.

Yellowtail, T., L. Anderson, I. Thom, T. Banyacya and P. Deere et al., 1980. Resolution of the 5th Annual Meeting of the Traditional Elders Circle. The Center for World Indigenous Studies Publication. http://www.yvwiiusdinvnohii.net/history/elders.html 